\title{
Maternal mortality according to race/skin color in Mato Grosso do Sul, Brazil, from 2010 to 2015
}

Renata Palópoli Pícoli 1

Luiza Helena de Oliveira Cazola 2

Everton Ferreira Lemos 3

1 Fundação Oswaldo Cruz de Mato Grosso do Sul. Rua Gabriel Abrão, 92. Jardim das Nações. Campo Grande, MS, Brasil. CEP: 79.081-746. E-mail: reppicoli@gmail.com

2 Universidade Anhanguera - Uniderp. Campo Grande, MS, Brasil.

3 Universidade Federal de Mato Grosso do Sul. Campo Grande, MS, Brasil.

\begin{abstract}
Objectives: to investigate the epidemiological profile, by race/skin color, of maternal deaths in the state of Mato Grosso do Sul, Brazil.

Methods: the present epidemiological study of maternal death distribution by race/skin color was based on data extracted from Brazilian mortality and livebirth information systems from 2010 to 2015. The maternal mortality ratio and the specific maternal mortality ratio were calculated and analyzed according to obstetric variables.

Results: the death risk for black $(R R=4.3, C 195 \%=2.08-8.71)$ and indigenous women $(R R=3.7, C I 95 \%$ 2.2-6.23) was approximately fourfold in comparison to the risk for white women. For direct causes of death, the state of Mato Grosso do Sul showed higher levels, $74.1 \%$, as well as for most races/skin colors in the first triennium. The specific maternal mortality ratio was higher among black and indigenous women aged30 to 39 years old (416.7 and 651.8 , respectively) per 100,000 live births $(p<0.05)$.

Conclusions: higher maternal mortality ratio for indigenous and black women and the predominance of deaths related to direct obstetric causes among race/skin color categories reflect inadequate health care during pregnancy and puerperium.
\end{abstract}

Key words Maternal mortality, Mortality registries, Information systems, Women's health 


\section{Introduction}

Maternal mortality (MM) is an indicator used to evaluate health and life conditions of women, given that it reflects the effectiveness of care policies during prenatal, childbirth and puerperium, ${ }^{1}$ in addition to revealing international disparities which emphasizes the development level of countries. ${ }^{2}$ Developing countries are responsible for $99 \%$ of maternal deaths, which demonstrates the geographicrelated disparity in death risk for pregnant women. ${ }^{2}$

In Latin America and the Caribbean, maternal mortality decreased $40 \%$ between 1990 and 2013.3 Although in the United States the mortality ratio is lower than in developing countries, the number more than doubled in the same period, increasing from 12 to 28 maternal deaths per 100,000 live births. 4

In Brazil, maternal mortality decreased from 141 to 68 deaths per 100,000 live births between 1990 and 2010 , which represents a $52 \%$ reduction in the mortality rate. However, the rate set by the United Nations' Millennium Development Goals was not met. The numbers also vary significantly among states, illustrating disparities in health care in different regions of the country. 5

Race/skin color should be seen not only as a biological aspect but also as a social variable that presents reduced health equity. The correct information of this characteristic in death certificates is important because it increases reliability of race data, allowing this indicator to be properly assessed in the three management spheres, with an ethnicalracial perspective. 6

Studies that examine the magnitude of racial disparities in maternal mortality are fundamental. In Brazil, this type of investigation is infrequent and points to higher mortality rates among black and indigenous women. 7,8

The current context indicates the relevance of studies about maternal mortality according to race/skin color so that researchers have supporting data to characterize racial disparities related to maternal deaths and to plan actions to decrease health inequities. The aim of the present study was to analyze the epidemiological profile of maternal deaths according to race/skin color in the state of Mato Grosso do Sul, Brazil.

\section{Methods}

The present study was epidemiological, descriptive and retrospective and evaluated maternal deaths according to race/skin color from 2010 to 2015 in the state of Mato Grosso do Sul. This state is located in the Central-West region of Brazil and has 79 cities, 2,449,024 inhabitants, and a territory of $357,145.836 \mathrm{~km}^{2} .9$

The characterization of race/skin color (white, indigenous, yellow, black and brown) filled in live birth and death certificates follows the categories established by the Brazilian Institute of Geography and Statistics. The yellow race/color is not present in the investigation because there were no records of maternal mortality of women with this skin color in the study period.

Data were extracted from the Brazilian Mortality Information System (SIM, as per its acronym in Portuguese) ${ }^{10}$ and the Live Birth Information System (Sinasc, as per its acronym in Portuguese), ${ }^{11}$ both with satisfactory coverage and data quality. For Sinasc, non-filling of the field race/skin color corresponded to $0.8 \%$ in 2010 and $0.1 \%$ in 2015 ; for SIM, $100 \%$ of the cases reported the color information.

Maternal death is defined as that resulting from obstetric complications related to pregnancy, childbirth, and puerperium. It can be caused by interventions, omissions, or inadequate treatment, which are classified as direct causes, or provoked by preexisting diseases or those that developed or worsened during pregnancy, categorized as indirect causes, until 42 days after childbirth. 12

The following obstetric variables were considered: (1) death period (during pregnancy, birth, miscarriage, or puerperium, until 42 days after birth); (2) types of direct and indirect obstetric deaths; (3) groups of causes according to the review of the list of the International Statistical Classification of Diseases and Related Health Problems (ICD 10). 12

Data were organized in tables in Excel software, with total numbers for the state and information regarding race / skin color.

The annual maternal mortality rate (MMR) was calculated according to race/skin color by using frequencies of maternal deaths and live births. The average MMR and the relative risk (RR) were estimated, also according to race/skin color, from 2010 to 2015 . For the latter, live births from each race/skin color category were considered as not affected in the studied period, and white skin color data were used as reference.

Specific maternal mortality rates for each race/skin color category were grouped into trienniums and used to count maternal deaths by sociodemographic variables (age group and years of education).

Epi Info 7 software was used to run the chi-square test for discrete numerical variables (age and 
years of education). A confidence interval of $95 \%$ and a significance level $\leq 0.05$ were adopted. Ignored information was discarded in the tests.

The study was approved by the Research Ethics Committee of the State University of MatoGrosso do Sul, under the protocol 1764050/2016.

\section{Results}

The state of Mato Grosso do Sul registered 166 maternal deaths in the period from 2010 to 2015 , from which 92 (55.4\%) involved brown women.

Maternal mortality rates for indigenous and black women (162.3 and 186.3 per 100,000 live births, respectively) were three to four times higher in comparison to the state rate, 65 per 100,000 live births. The death risk for black $(\mathrm{RR}=4.3$; $\mathrm{CI} 95 \%=$ 2.08-8.71) and indigenous $(\mathrm{RR}=3.7$; CI 95\% $=2.2$ $6.23)$ women was around four times higher than the index for white women (Table 1).

Regarding the distribution of MMRs, the state presented a decrease in the number of deaths from 74.9 to 52.2 per 100,000 live births from 2010 to 2013, but showed an increase in 2014 and 2015. For black women, the MMR peaked in 2010 (810.7 per 100,000 live births) and presented a significant decrease, with no registered death in 2013, and 91.5 and 233.4 deaths per 100,000 live births in 2014 and 2015, respectively (Figure 1).

The rate for indigenous women oscillated in the studied time interval, with highest values recorded in the years 2010 (293.5 per 100,000 live births), 2013 (223.5 per 100,000 live births) and 2015 (370.2 per 100,000 live births). In 2012 there was no record of maternal death in this racial group (Figure 1).

The white skin color group presented the lowest rates and little oscillation. Its rate varied from 43.9 to 39.2 deaths per 100,000 live births between 2010 and 2015. For the brown skin group, rates were close to the state value in $2015,59.3$ per 100,000 live births (Figure 1).

Regarding death period, there was a predominance of puerperium in the state $(58.5 \%$ and $51.3 \%$ in the two trienniums) and for the brown race/skin color (51.1\% and 55\%) (Table 2).

Direct causes of death were responsible for the highest contribution (74.1\%) to the general MMR and specific race/skin color rates in the first triennium. For the set of direct causes related to labor and delivery complications, there was a predominance of indigenous and white women, with $83.3 \%$ and $44.4 \%$, respectively, and those associated with edema, proteinuria and hypertensive disorders of pregnancy were the main cause of death among black women $(50 \%)$. The state registered a rate of death by indirect causes of $25.9 \%$, a percentage similar to that observed for indigenous, white and brown races (Table 2).

Regarding the second triennium, the state data showed a decrease in the rate associated with direct causes $(60.8 \%)$. The brown race/skin group presented the lowest rate, with $54.8 \%$. Miscarriage was the main direct cause of death, with the highest percentages in the state. As for complications related to puerperium, the values extracted from the databases were $37.5 \%, 26.7 \%$ and $21.7 \%$, respectively, for indigenous, white and brown races/skin colors. The group of causes that encompassed edema, proteinuria and hypertensive disorders in pregnancy was responsible for $21.7 \%$ of the events in brown women and $50 \%$ of the episodes in black women (Table 2).

The rates of maternal mortality provoked by indirect causes were higher in the second triennium (39.2\% vs. $25.9 \%)$. Highest values were registered for the brown race $(45.2 \%)$ and lowest for the white race $(28.6 \%)$ (Table 2$)$.

In the analysis of specific MMRs, there was a predominance of women aged 40 to 49 years old in both trienniums in the state (143.1 and 209.6 deaths per 100,000 live births, respectively). The same trend was observed for the brown color, with 309 and 237.5 deaths per 100,000 live births. For the indigenous race, the age group $30-39$ years old prevailed. In the first triennium, extreme specific rates were associated with black (416.7 deaths per 100,000 live births) and white women (60.7 deaths per 100,000 live births), whereas in the second triennium indigenous women replaced black women in the rank (651.8 deaths per 100,000 live births); and white women kept the lowest rates (47.7 deaths per 100,000 live births). There was a statistically significant correlation between race/skin color and age group in both trienniums (Table 3 ).

Maternal deaths among indigenous women were more common in women with less than three years of education in both trienniums (228.8 and 230.4 deaths per 100,000 live births). For brown women, the mortality rate was higher for women with no formal education (378.8 and 426.4 deaths per 100,000 live births). The second triennium showed a statistically significant correlation between race/skin color and years of education (Table 3).

\section{Discussion}


Maternal mortality rate and relative risk according to race/skin color. MatoGrossodoSul, 2010 to 2015.

\begin{tabular}{|c|c|c|c|c|c|c|c|c|}
\hline \multirow{2}{*}{ Race / Skin color } & \multicolumn{2}{|c|}{ Deaths } & \multicolumn{2}{|c|}{ Live births } & \multirow{2}{*}{ MMR } & \multirow{2}{*}{$\mathbf{R R}$} & \multirow{2}{*}{$\mathrm{Cl} 95 \%$} & \multirow{2}{*}{$p^{1}$} \\
\hline & $\mathrm{n}$ & $\%$ & $\mathrm{n}$ & $\%$ & & & & \\
\hline White & 44 & 26.5 & 100,554 & 39.4 & 43.7 & 1.0 & - & - \\
\hline Brown & 92 & 55.4 & 134,946 & 52.9 & 68.2 & 1.6 & $1.1-2.2$ & $<0.001$ \\
\hline Indigenous & 21 & 12.6 & 12,939 & 5.1 & 162.3 & 3.7 & $2.2-6.2$ & $<0.001$ \\
\hline Black & 9 & 5.5 & 4,830 & 1.9 & 186.3 & 4.3 & $2.1-8.7$ & $<0.001$ \\
\hline Total & 166 & 100.0 & 255,253 & 100.0 & 65.0 & - & - & - \\
\hline
\end{tabular}

Source: DATASUS, 2016.

$1 p<0.05 ;$ MMR: maternal mortality ratio; RR: relative risk.

\section{Figure 1}

Maternal mortality rate according to race/color. Mato Grosso do Sul, 2010 to 2015.

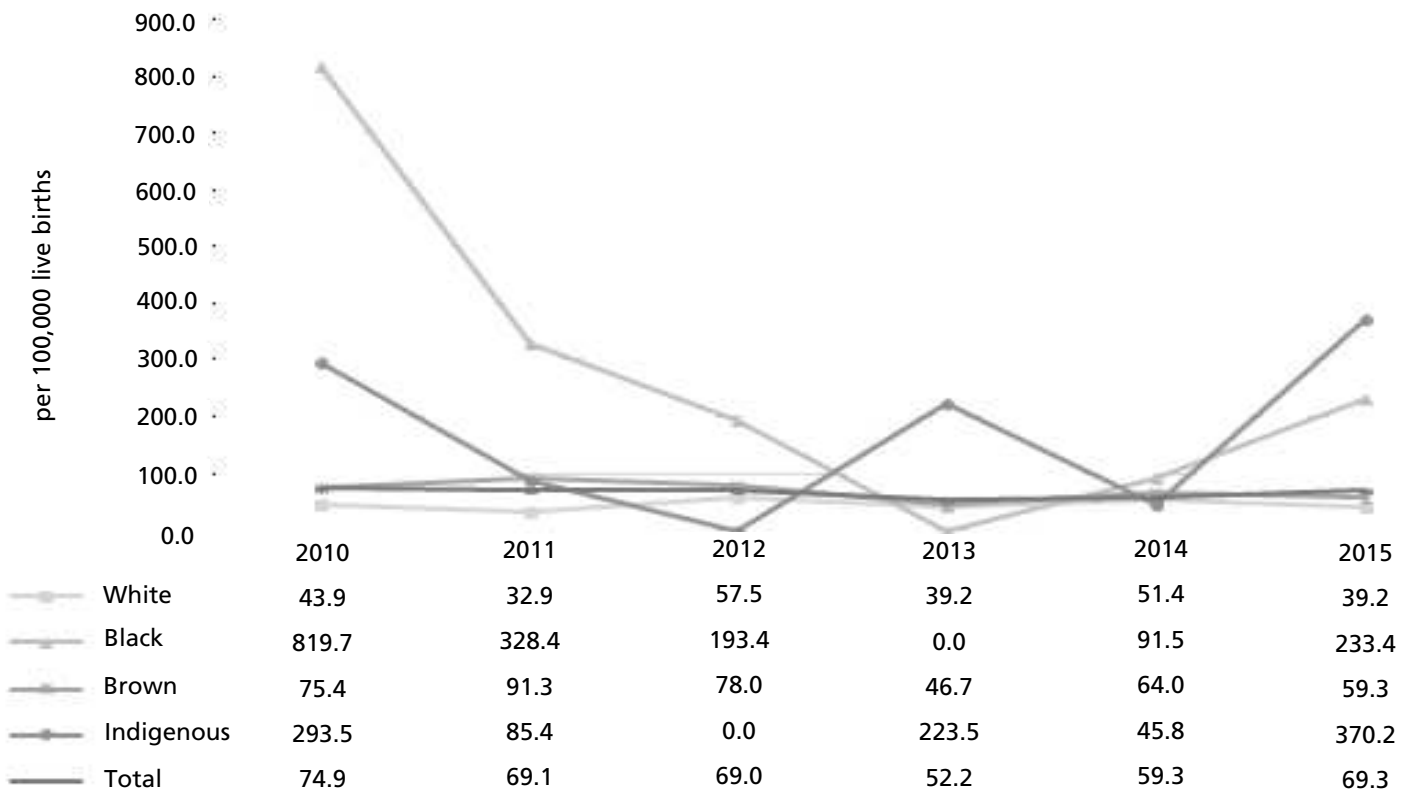


Distribution of frequencies of maternal deaths by direct and indirect obstetric causes according to race/skin color. Mato Grosso do Sul, 2010 to 2015

\begin{tabular}{|c|c|c|c|c|c|c|c|c|c|c|}
\hline \multirow{2}{*}{ Variables } & \multicolumn{2}{|c|}{ Indigenous } & \multicolumn{2}{|c|}{ White } & \multicolumn{2}{|c|}{ Black } & \multicolumn{2}{|c|}{ Brown } & \multicolumn{2}{|c|}{ Total } \\
\hline & $\mathrm{n}$ & $\%$ & $\mathrm{n}$ & $\%$ & $\mathrm{n}$ & $\%$ & $\mathrm{n}$ & $\%$ & $\mathrm{n}$ & $\%$ \\
\hline \multicolumn{11}{|c|}{$2010-2012$} \\
\hline \multicolumn{11}{|l|}{ Death period } \\
\hline During pregnancy, childbirth or miscarriage & 4 & 50 & 8 & 33.3 & 3 & 50 & 22 & 44.9 & 35 & 41.2 \\
\hline During puerperium, until 42 days after birth & 4 & 50 & 16 & 66.7 & 3 & 50 & 27 & 51.1 & 50 & 58.5 \\
\hline Direct obstetric causes* & 6 & 75 & 18 & 75 & 4 & 66.7 & 35 & 73 & 63 & 74.1 \\
\hline $\begin{array}{l}\text { Oedema, proteinuria and hypertensive disor- } \\
\text { ders in pregnancy, childbirth and the puer- } \\
\text { perium (010-016) }\end{array}$ & 1 & 27.7 & 6 & 33.3 & 2 & 50 & 10 & 28.6 & 19 & 30.1 \\
\hline $\begin{array}{l}\text { Other maternal disorders predominantly rela- } \\
\text { ted to pregnancy (O20-029) }\end{array}$ & 0 & - & 0 & - & 0 & - & 2 & 5.7 & 2 & 3.2 \\
\hline Pregnancy with abortive outcome (O00-008) & 0 & - & 2 & 11.1 & 0 & - & 7 & 20 & 9 & 14.2 \\
\hline $\begin{array}{l}\text { Complications of labor and delivery (O60 - } \\
\text { O75) }\end{array}$ & 5 & 83.3 & 8 & 44.4 & 1 & 25 & 7 & 20 & 21 & 33.3 \\
\hline $\begin{array}{l}\text { Complications predominantly related to the } \\
\text { puerperium (085-092) }\end{array}$ & 0 & - & 2 & 11.1 & 1 & 25 & 5 & 14.3 & 8 & 12.9 \\
\hline $\begin{array}{l}\text { Maternal care related to the fetus and amnio- } \\
\text { tic cavity and possible delivery problems } \\
\text { (030 - O48) }\end{array}$ & 0 & - & 0 & - & 0 & - & 4 & 11.4 & 4 & 6.3 \\
\hline Indirect obstetric causes & 2 & 25 & 6 & 25 & 2 & 33.3 & 13 & 27 & 21 & 25.9 \\
\hline $\begin{array}{l}\text { Other obstetric conditions, not elsewhere } \\
\text { classified (095 - 099) }\end{array}$ & 2 & 100 & 6 & 100 & 2 & 100 & 13 & 100 & 21 & 100 \\
\hline \multicolumn{7}{|c|}{$2013-2015$} & & & & \\
\hline During pregnancy, childbirth or miscarriage & 7 & 53.8 & 11 & 55.0 & 1 & 33.3 & 18 & 45.0 & 37 & 48.7 \\
\hline During puerperium, until 42 days after birth & 6 & 46.2 & 9 & 45.9 & 2 & 66.7 & 22 & 55.0 & 39 & 51.3 \\
\hline Direct obstetric causes & 8 & 61.5 & 15 & 71.4 & 2 & 66.7 & 23 & 54.8 & 48 & 60.8 \\
\hline $\begin{array}{l}\text { Oedema, proteinuria and hypertensive disorders } \\
\text { in pregnancy, childbirth and the puerperium }\end{array}$ & 0 & - & 3 & 20.0 & 1 & 50.0 & 5 & 21.7 & 9 & 18.7 \\
\hline$(010-016)$ & 1 & 12.5 & 2 & 13.3 & 0 & - & 0 & - & 3 & 6.3 \\
\hline Other maternal disorders predominantly related & & & & & & & & & & \\
\hline to pregnancy (O20 - O29) & 2 & 25.0 & 4 & 26.7 & 1 & 50.0 & 4 & 17.4 & 11 & 22.9 \\
\hline $\begin{array}{l}\text { Pregnancy with abortive outcome (000-008) } \\
\text { Complications of labor and delivery (060-075) }\end{array}$ & 1 & 12.5 & 2 & 13.3 & 0 & - & 5 & 21.7 & 8 & 16.7 \\
\hline $\begin{array}{l}\text { Complications predominantly related to the } \\
\text { puerperium (085-092) }\end{array}$ & 3 & 37.5 & 4 & 26.7 & 0 & - & 5 & 21.7 & 12 & 25.0 \\
\hline $\begin{array}{l}\text { Maternal care related to the fetus and amnio- } \\
\text { tic cavity and possible delivery problems } \\
\text { (O30 - O48) }\end{array}$ & 1 & 12.5 & 0 & - & 0 & - & 4 & 17.4 & 5 & 10.4 \\
\hline Direct obstetric causes & 5 & 38.5 & 6 & 28.6 & 1 & 33.3 & 19 & 45.2 & 31 & 39.2 \\
\hline $\begin{array}{l}\text { Other obstetric conditions, not elsewhere classi- } \\
\text { fied (095- 099) }\end{array}$ & 5 & 100.0 & 6 & 100.0 & 1 & 100.0 & 19 & 100.0 & 31 & 100.0 \\
\hline
\end{tabular}

Source: DATASUS, 2016.

*Obstetric cause not specified for one white and two brown women in the first triennium. **Death period not informed or ignored for one white and one brown women in the second triennium. 
Specific maternal mortality rate according to race/skin color by age group and years of education. Mato Grosso do Sul, 2010 to 2015.

\begin{tabular}{|c|c|c|c|c|c|c|}
\hline \multirow{2}{*}{ Variables } & \multicolumn{5}{|c|}{ Specific maternal mortality rate } & \multirow[b]{2}{*}{ Total } \\
\hline & Indigenous & White & Black & Brown & $p^{1}$ & \\
\hline & \multicolumn{6}{|c|}{$2010-2012$} \\
\hline \multicolumn{7}{|l|}{ Age group } \\
\hline 10 to 19 years old & 0 & 39.6 & 257.7 & 54.3 & $<0.167$ & 47.1 \\
\hline 20 to 29 years old & 131.9 & 38.6 & 305.8 & 55.2 & $<0.001$ & 55.3 \\
\hline 30 to 39 years old & 378.9 & 60.7 & 416.7 & 164.4 & $<0.001$ & 123.6 \\
\hline 40 to 49 years old & 0 & 0 & 0 & 309.0 & $<0.324$ & 143.1 \\
\hline \multicolumn{7}{|l|}{ Years of education* } \\
\hline None & 149 & 0 & 0 & 378.8 & $<0.683$ & 201.5 \\
\hline 1 to 3 years & 228.8 & 236.1 & 0 & 71.4 & $<0.452$ & 152.5 \\
\hline 4 to 7 years & 100.9 & 17.9 & 340.7 & 87.9 & $<0.008$ & 70.4 \\
\hline 8 to 11 years & 0 & 42.8 & 309.3 & 65.2 & $<0.005$ & 58.1 \\
\hline 12 years or more & 0 & 33.1 & 515.5 & 66.1 & $<0.163$ & 46.5 \\
\hline \multicolumn{7}{|c|}{$2013-2015$} \\
\hline \multicolumn{7}{|l|}{ Age group } \\
\hline 10 to 19 years old & 174.2 & 66.7 & 0.0 & 35.5 & $<0.055$ & 55.1 \\
\hline 20 to 29 years old & 70.8 & 30.4 & 68.5 & 59.8 & $<0.415$ & 50.2 \\
\hline 30 to 39 years old & 651.8 & 47.7 & 229.9 & 58.0 & $<0.001$ & 76.8 \\
\hline 40 to 49 years old & 0 & 214.4 & 0 & 237.5 & $<0.931$ & 209.6 \\
\hline \multicolumn{7}{|l|}{ Years of education* } \\
\hline None & 0 & 0 & 0 & 426.4 & $<0.491$ & 193.1 \\
\hline 1 to 3 years & 230.4 & 177.3 & 934.6 & 108.7 & $<0.256$ & 326.1 \\
\hline 4 to 7 years & 337.7 & 77.4 & 135.9 & 47.9 & $<0.001$ & 87.1 \\
\hline 8 to 11 years & 94.7 & 41.6 & 433.4 & 37.2 & $<0.001$ & 49.0 \\
\hline 12 years or more & 0 & 37.6 & 233.6 & 87.5 & $<0.185$ & 58.5 \\
\hline
\end{tabular}

Source: DATASUS, 2016.

$1 p<0.05 ;$ * Years of education ignored for one indigenous, two white and four brown women in the first triennium and for ten brown women in the second triennium.

The present investigation emphasized a decrease in maternal mortality rates in the state of Mato Grosso do Sul in general and for all the race/skin color groups, except the indigenous one. As for the death period, most events occurred during puerperium, and direct obstetric causes were more common in every race category. Maternal death risk was higher for older women with few years of education

In Brazil, 13 the estimated general MMR between 2009 and 2011 was 68.2 deaths per 100,000 live births, and the value for Mato Grosso do Sul was 76.4 deaths per 100,000 live births. These numbers are higher than the outcomes highlighted by the present study, which reported an average of 65 maternal deaths per 100,000 live births, with a downward trend during the analyzed historical data series.

Despite this trend, it is possible to classify current rates as high for the state in general and very high for indigenous and black people, given that international guidelines categorize MMRs as low for values inferior to 20 deaths per 100,000 live births, intermediate for values between 20 and 49 deaths per 100,000 live births, high for values between 50 and 149 deaths per 100,000 live births and very high for values over 150 deaths per 100,000 live births. ${ }^{2}$

The indigenous and black races/skin colors showed the worst results and the largest disparity in comparison to the rates for white women, with a maternal death risk four times higher than the probability for white mothers. A similar result was 
reported in the United States, where black mothers are exposed to a higher risk of death.14 In the state of Paraná, the risk of maternal death in the period from 2000 to 2002 was 8.2 times higher for black women, using white women's rate as a reference, ${ }^{7}$ a ratio higher than that revealed by the present study.

Most analyzed maternal deaths involved brown women, in accordance with other outcomes in Brazil: $42.7 \%$ in the country from 2000 to 2009,15 and $69.7 \%$ in Recife, state of Pernambuco, from 2001 to 2005.16

Although race is a social construct, which encompasses several aspects from a person's history, ethnical-social studies point to a social inequality in society, illustrated by socioeconomic positions, iniquity in access to healthcare services and low quality of care. 17

In the present study, the most common period of death was the puerperium. This outcome deserves attention by healthcare professionals, given that the improvement of access to healthcare services, professional training, and proper intervention measures 18 can contribute to reducing the number of deaths.

A similar investigation 8 revealed that, for the state as a whole, direct causes such as edema, proteinuria, and hypertensive disorders in pregnancy were responsible for the highest death percentages for black (45.4\%) and brown (29.9\%) races, numbers that resemble the findings of the present study.

Deaths provoked by direct, that is, preventable causes, are associated with delayed care, both in detection of complications in time and the use of proper interventions or adequate application of the services available in women's reproductive healthcare network. ${ }^{1}$ This is a possible explanation for the disparity between MMRs and the improvement of prenatal, childbirth and puerperium care indicators. ${ }^{19}$ Miscarriages were the second direct cause of maternal deaths, with higher percentages in the state. Miscarriage risk is three times higher for black women than for white women.?

Another aspect that must be considered is abortion. This conduct is illegal in Brazil, a fact that does not prevent its practice. Incorrect procedures commonly result in deaths that are not counted in maternal mortality statistics. 20

Regarding sociodemographic factors, a correlation between age and maternal death risk was found, given that the higher the age, the higher the specific MMR. This result was found for most races/skin colors. A study carried out in African countries showed that older women that undergo pregnancy have a higher death risk. 21
In the state of Rio Grande do Sul,22 the specific MMR for women aged 40 to 49 years old was high between 1999 and 2008 and similar to the value described in the present study. Mato Grosso do Sul had high maternal death percentages for indigenous women $(36.4 \%)$ in the age group $30-39$ years old and for the other races/colors in the age group $20-$ 29 years old.

For the state as a whole and for indigenous and brown women, a negative correlation between MMR and years of education was found, that is, the poorer the level of education, the higher the death risk. This outcome can result in reduced access to healthcare services and low prenatal, childbirth and puerperium care quality, stressing the magnitude of social health disparities.

In countries with significant inequalities in access to education, such as Brazil, the number of years of education is an important socioeconomic indicator. 23 A study carried out in Brazilian capital cities identified a higher death risk for women with less than four years of education. 24 A low educational level can hinder access to information and healthcare services essential to a healthy pregnancy and the awareness of citizen's rights. 25

Although MMRs according to race have shown a higher death risk for some ethnical-racial groups, there are complex aspects related to socioeconomic positions and racial health inequity that must be examined in future investigations.

The main limitation of the present study is the fact that its findings are based on secondary data. There is underreporting in the completion of death certificates and lack of clarity in race/skin color classification, as exemplified by the absence of maternal deaths for indigenous and black women in 2012 and 2013, respectively.

Nevertheless, the consulted databases are considered to have better quality regarding filling of the race/skin color field in comparison to other Brazilian health systems, such as the Notifiable Diseases Information System (Sinan, as per its acronym in Portuguese) and the Hospital Information System (SIH, as per its acronym in Portuguese). Another relevant limitation refers to the grouping of specific MMRs for sociodemographic variables and the occurrence of maternal deaths according to obstetric variables, which may hinder a more detailed analysis when the isolated annual data are considered.

The general maternal mortality in the state of Mato Grosso do Sul, as well as the rates for specific race categories, characterized by a high death risk and deaths related to direct obstetric causes, reflects healthcare conditions that women experience during 
pregnancy and puerperium. If maternal mortality is construed as a sentinel event, it allows the identification of deficiencies in care and the implementation of actions in time to improve the quality of services offered to the population.

\section{References}

1. Souza JP. Mortalidade materna no Brasil: a necessidade de fortalecer os sistemas de saúde. Rev Bras Ginecol Obstet. 2011; 33 (10): 273-9.

2. WHO (World Health Organization). Trends in maternal mortality: 1990 to 2015: estimates by WHO, UNICEF, UNFPA, World Bank Group and the United Nations Population Division. Geneva; 2015. [acesso em jan 2017]. Disponível em: https://data.unicef.org/wp-content/ uploads/2015/12/Trends-in-MMR-1990-2015_Fullreport_243.pdf.

3. OPAS (Organizacíon Panamericana de La Salud) Reducción mortalidad materna en 11 países de laRegión. Washington;.2014. [acesso em jan 2017]. Disponível em: http://www.paho.org/clap/index.php?option=com_content $\&$ view $=$ article \&id=220-reduccion-mortalidad-materna-en11 -paises-de-la region $\&$ catid $=387 \&$ Itemid $=354 \&$ lang $=e s$

4. Agrawal P. Maternal mortality and morbidity in the United States of America. Bull World Health Organ. 2015; 93 (3): 135

5. Brasil. Ministério da Saúde. Boletim Epidemiológico Mortalidade Materna. Brasília, DF; 2012. [acesso em jan 2017]. Disponível em: http://u.saude.gov.br/images/pdf/ 2014/julho/23/BE-2012-43--1--pag-1-a-7---MortalidadeMaterna.pdf

6. Braz RM, Oliveira PTR, Reis AT, Machado NS. Avaliação da completude da variável raça/cor nos sistemas nacionais de informação em saúde para aferição da equidade étnicoracial em indicadores usados pelo Índice de Desempenho do Sistema Único de Saúde. Saúde em Debate. 2013; 37 (99): 554-62.

7. Martins AL. Mortalidade materna de mulheres negras no Brasil. Cad Saúde Pública. 2006; 22 (11): 2473-9.

8. Teixeira NZF, Pereira WR, Barbosa DA, Vianna LAC. Mortalidade materna e sua interface com a raça em Mato Grosso. Rev Bras Saúde Mater Infant. 2012; 12 (1): 27-35.

9. Brasil. Instituto Brasileiro de Geografia e Estatística. Censo demográfico e contagem da população, Brasil 2010. Brasília, DF; 2010. (acesso em 2016 dez 10). Disponível em: https://www.ibge.gov.br/home/estatistica/populacao/ censo2010/default_resultados_amostra.shtm

10. Brasil. Sistema de Informações sobre Mortalidade - SIM. DATASUS. Tecnologia da Informação a Serviço SUS Brasília, DF; 2017. [acesso em jun 2017]. Disponível em http://tabnet.datasus.gov.br/cgi/sim/Ob_Mu Id Fertil_Mat 1996 2012.pdf

11. Brasil. Sistema de Informações de Nascidos Vivos Sinasc. DATASUS. Tecnologia da Informação a Serviço SUS. Brasília, DF; 2017. [acesso em jun 2017]. Disponível

em: http://tabnet.datasus.gov.br/cgi/sinasc/Nascidos Vivos_1994_2012.pdf

12. Organização Mundial da Saúde. Classificação estatística internacional de doenças e problemas relacionados à saúde. In: instrução Médica, editor. $10^{\mathrm{a}}$ revisão ed. São Paulo: Edusp; 2008.

13. Szwarcwald CL, Escalante JJC, Rabello Neto DL, Souza Junior PRB, Victora CG. Estimação da razão de mortalidade materna no Brasil, 2008-2011. Cad Saúde Pública. 2014; 30 (Supl.1): S71-83.

14. Tucker MJ, Berg CJ, Callaghan WM, Hsia J. The Black-White Disparity in Pregnancy-Related Mortality From 5 Conditions: Differences in Prevalence and CaseFatality Rates. Am J Public Health. 2007; 97 (2): 247-51.

15. Ferraz L, Bordignon M. Mortalidade materna no Brasil: uma realidade que precisa melhorar. Rev Baian Saúde Pública. 2013; 36 (2): 527-38.

16. Leite RMB, Araújo TVB, Albuquerque RM, Andrade ARS, Duarte Neto PJ. Fatores de risco para mortalidade materna em área urbana do Nordeste do Brasil. Cad Saúde Pública. 2011; 27 (10): 1977-85.

17. Chor D. Desigualdades em saúde no Brasil: é preciso ter raça. Cad. Saúde Pública. 2013; 29 (7): 1272-75.

18. Rosenstein MG, Romero M, Ramos S. Maternal mortality in Argentina: a closer look at women who die outside of the health system. Matern Child Health J. 2008; 12 (4): 519-24.

19. Victora CG, Aquino EML, Leal MC, Monteiro CA, Barros FC, Szwarcwald CL. Maternal and child health in Brazil: progress and challenges. Lancet. 2011; 377: 29-42.

20. Singh S. Hospital admissions resulting from unsafe abortion: estimates from 13 developing countries. Lancet. 2006; 368: $1887-92$

21. Evjen-Olsen B, Hinderaker SG, Lie RT, Bergsjo P, Gasheka $\mathrm{P}$, Kvale G. Risk factors for maternal death in the highlands of rural northern Tanzania: a case-control study. BMC Public Health. 2008; 8 (1): 52-60.

22. Carreno I, Bonilha ALL, Costa JSD. Temporal evolution and spatial distribution of maternal death. Rev Saúde Pública. 2014; 48 (4): 662-70.

23. Hogan MC, Foreman KJ, Naghavi M, Ahn SY, Wang M, Makela SM, Lopez AD, Lozano R, Murray CJL. Maternal mortality for 181 countries, 1980-2008: a systematic analysis of progress towards Millennium Development Goal 5. Lancet. 2010; 375 (9726):1609-23.

24. Laurenti R, Mello JM, Gotlieb SLD. A mortalidade materna nas capitais brasileiras: algumas características e estimativa de um fator de ajuste. Rev Bras Epidemiol. 2004; 7 (4): $449-60$ 
25. United Nations. Millennium Development Goals. New York: United Nations; 2011 (cited $2016 \mathrm{dez} 7$ ).

Availablefrom: http://www.un.org/millenniumgoals/ bkgd.shtml

Received on May 10, 2017

Final version presented on June 27, 2017

Approved on July 31, 2017 